Accepted manuscript. The original article has been published in Emotion, Space and Society 2019,32, 100541. https://doi.org/10.1016/j.emospa.2018.08.002. For citation, please use the original.

\title{
LEADING REFUGEE LIVES TOGETHER: FAMILIAL AGENCY AS A POLITICAL CAPACITY
}

Author: Kirsi Pauliina Kallio

Space and Political Agency Research Group (SPARG), RELATE Centre of Excellence, University of Tampere, Finland

\section{Abstract}

Family life is constituted by affective relationships and emotional bonds between individuals connected through kinship, yet in many cases involving people from beyond the lineal descent group as well. In precarious migratory processes and situations, the significance of these relations often grows. Even if put under increased pressure, they encompass important resources that individuals alone could not possess. Then again, for some people certain familial relations are part of the problematized life situation, challenging rather than reinforcing their personal agency. This paper explores political dimensions of refugee agency and discusses how mundane familial political agency is acquired and practiced in refugee situations. Specifically, analyzed are intimate relationships as unfolding in some young male refugees' transnational lives, as personal and shared experiences and practices. The paper takes notice of conflicted familial relations, too, to create a better understanding about the manifoldness of intergenerational political agencies. Drawing from interviews with Iraqi, Afghan and Somali refugees, it demonstrates how familial agency is irreducible to the personal agencies of family members yet does not exist beyond subjective stances. In conclusion, the paper proposes that familial mundane politics remain poorly noticed in refugee situations, which harmfully effects on the humanitarian aid system as well as refugee lives.

\section{Introduction}

The question of how people may engender and practice mundane political agency as part of their families is at the heart of this paper. Specifically, the focus is on the familial relations and agencies of refugees who face the request to establish themselves as refugees in the communities and societies where they seek 
Author's copy. The original article has been published in Emotion, Space and Society (online 1 September 2018, doi.org/10.1016/j.emospa.2018.08.002). For citation, please use the original.

asylum, which requires from them various kinds of agential capacities. The thus emerging subjectivities, identities and agencies, which I have studied with my colleagues as processes of 'becoming refugee', are subjectively experienced and enacted but also shared and practiced with other individuals and collectives. Our recent studies with refugees in Cairo, Egypt and Southern Finland demonstrate that familial relations hold a central place in these mundane politics (Häkli et al. 2017; Kallio and Häkli 2018; Pascucci et al. 2018; Kallio et al. forthcoming). Drawing from this research the paper will suggest that, as familialities are shared in intergenerational encounters by refugees, such emotional sharing may generate 'familial agency' as a political capacity.

The concept of familiality stands for an open-ended conception of familial life, approaching it from people's experiences and practices. It refers to caring intergenerational relationships of fluctuating intensities that people form in their intimate lives throughout the lifecourse. The approach sets out to challenge categorical conceptions of the family, manifested prominently by the Western nuclear family ideal based on a specific scope of the family, hierarchical and fixed generational relations, blood lineage and descent, and kinship institutionally defined (Kallio and Häkli 2018, also Kallio 2012, 2014, 2016a, 2016b). Many refugees find themselves negotiating between different family conceptions.

In its various forms, familiality is typically analyzed through individual agencies, as practiced by different family members who act in the roles of parents and grandparents, sons and daughters, siblings and cousins, aunts and uncles, et cetera. Even when acting together or for similar aims, people are commonly seen as individuals or as representatives of their reference group (e.g. Erel 2011; Baak 2015; Kivistö and VecchiaMikkola 2015; Williams 2015). A slightly different approach can be taken by looking into how people act as families, which is not to deny or downplay their personal agencies.

Beier and her colleagues suggest that, "Directing attention to decision-making in the family as a family can lead us to a fundamental reassessment of certain practices from an ethical point of view" (2016, p.412, emphasis in original). Following a similar idea, Evans (2013, p.238) has analyzed how siblings practice solidarity and commitment for their household by "living with" each other. This sisterly and brotherly agency is not detached from parental agency that, in the discussed case, is limited by the (single) parents' 
Author's copy. The original article has been published in Emotion, Space and Society (online 1 September 2018, doi.org/10.1016/j.emospa.2018.08.002). For citation, please use the original.

serious illness (also Hanrahan 2018). In these situations, where adequate extra-familial caring is not available, intergenerational responsibility for the family intensifies, involving children and parent alike as active participants (also Lind 2018). In the international migration context, Duque-Páramo (2013, p.2014) similarly describes how families living in separation may "share the sacrifice" for familial good, and Peña and Ybarra (2017, p.40) talk about "collective pain" as a source of political familial agency in such situations. In addition to mutual agency, these scholars all recognize family members as particular persons with different subject positions, who also act independently of and with reference to each other.

Following these lines of thinking, this article scrutinizes how people in refugee situations may act concurrently as individuals, with personal feelings and conceptions, and by relying on (but sometimes also challenging) emotionally embedded shared familialities. It approaches political agency as an intergenerationally developing, subjectively established human capacity that provides people potential to act for and against things important to them, as individuals as well as collectively. Besides public and overtly political acts, these activities essentially include affective agency mobilizing in mundane encounters and generating 'aged' relationships with emotional underpinnings.

The next section describes the context of the study. Then I introduce the theoretical and methodological starting points, and the studies I draw from. The analytical sections focus on the mundane politics of young refugee men and boys whose political agencies, particularly, tend to be linked with public and collective activities, instead of affective encounters, emotional ties, or intimate relations. In conclusion, the lack of acquaintance with and acknowledgment of intergenerational political agency is discussed as a hindrance that leads to undermining refugees' self-established active agencies.

\section{Politics of refugee familiality}

Familial relations often carry an important role in preparing and carrying out refugee journeys, including broad cultural variety. Similarly, while people wait for their applications to be processed, they rely on their existing social networks that at once keep them connected in their transnational lived worlds and open up opportunities to extending these realities through new contacts. In situations following the asylum seeking 
Author's copy. The original article has been published in Emotion, Space and Society (online 1 September 2018, doi.org/10.1016/j.emospa.2018.08.002). For citation, please use the original.

process, familial refugee lives are continued in varying ways. Opportunities to maintain existing family relations and create new ones are largely dependent on refugee policies that do not always recognize or set out to support familialities as experienced and practiced by refugees (Hayden 2006). Quite the opposite, current refugee policies around the world tend to emphasize individuality at the cost of familiality (e.g. Lippert and Pyykkönen 2012; Hedlund 2017; Honkasalo et al. 2017; Kallio and Häkli 2018; Lind 2018; Jacobsen forthcoming; Mitchell and Sparke forthcoming).

Drawing from the 1951 Refugee Convention of the United Nations High Commissioner for Refugees (UNHCR), many countries consider individual persecution critical in their decisions of status determination, instead of more general oppression or violence, or refugees' rights to family life as outlined by the United Nations Human Rights Committee (1990) (also UNHCR 2001). People seeking asylum as families may thus continue to live together only if the family members are all - individually - recognized as refugees. Even when this happens, the parts of the family staying in the country of origin or residing in other places will typically remain far-off. With them, refugees may apply for family reunion yet, in many cases, it is made very difficult. The right is restricted to specific family members with particular family histories, opportunities to application are offered in unattainable locations, and the right can be denied tout court based on a temporary refugee status for instance (Honkasalo et al. 2017; Lind 2018; Jacobsen forthcoming). In countries like Egypt and Jordan most refugees do not gain opportunities to relocation or reunion at all, even if gaining the status, but are compelled to continue their lives in refugee camps or at urban fringes, or alternatively continue their journeys as irregular migrants (Pascucci 2016, 2018; Pascucci et al. 2018).

If the familial situations of recognized refugees can be challenging, this is ever more apparent for the people whose applications for international protection are not accepted. They have meager opportunities to any humanitarian aid and are thus compelled to lead familial lives as irregularized migrants or forced returnees, relying mostly on their social networks. Familial relations and agencies tend to transform in such situations as people have little resources to care for their families and urgent needs for familial support. Furthermore, to some refugees, certain familial relations may be part of the reason for seeking asylum, which again changes how familiality is present in their lives (Kallio and Häkli 2018). These aspects, too, are 
Author's copy. The original article has been published in Emotion, Space and Society (online 1 September 2018, doi.org/10.1016/j.emospa.2018.08.002). For citation, please use the original.

often misrecognized in humanitarian practices. For example, women escaping forced marriage and exploitation, and children running away from violent families or sexual abuse, may receive little support regarding their experienced familialities.

The majority of migrants in precarious situations have strong familial interests and hopes, involving various kinds of emotional and intergenerational relationships (e.g. Sassoon 2008; Spellings et al. 2012; Duque-Páramo 2013; Williams 2015; Pascucci 2016; Peña and Ybarra 2017; Lind 2018; Jacobsen forthcoming). Depending on their life situations and cultural backgrounds, refugee families may aim at establishing a new life in a safe location, and young people may seek to form a family once in an opportune environment. Supporting family members from a distance, in the country of origin or elsewhere, is another common aspect (e.g. Baak 2015). Related to that, one form of migration is to prepare someone from the family - often boy or young man - to the dangerous and expensive trip that most family members could not take, with reunion and/or support over distance in mind. These forms of familial agency have proved particularly challenging to encounter in the humanitarian aid system that sets out to provide protection to individual persons in the country of residence.

The individual right to seek and enjoy asylum is often emphasized by states, as well as the UNHCR offices, leaning on the Article 14 of the Universal Declaration of Human Rights (UDHR). This contrasts the United Nations' (1983) guidelines on the unity of the family as an essential right of the refugee. Especially, familial relations beyond the nuclear family structure are overlooked (Harker 2010), which the UNHCR (2001) statement on families sees as a wrong interpretation of refugee familiality. The Commissioner emphasizes that "economic and emotional relationships between refugee family members be given equal weight and importance in the criteria for reunification as relationships based on blood lineage or legally sanctioned unions", because refugees "depend on each other for mutual support and survival [and] may not fit neatly into preconceived notions of a nuclear family" (UNHCR 2001, emphases added). Concerting this, the Commissioner for Human Rights at the Council of Europe (2017, emphasis added) recently ushered the states towards "flexible assessment of the emotional, social, financial and other ties and supports between refugees and family members". 
Author's copy. The original article has been published in Emotion, Space and Society (online 1 September 2018, doi.org/10.1016/j.emospa.2018.08.002). For citation, please use the original.

Current examples of unfamilial refugee policies and practices can be found in Finland, among other Nordic countries (cf. Lind 2018; Jacobsen forthcoming). The national media has broadly publicized cases where, to give a couple of examples, a girl who had just come of age received a deportation request as she was not anymore considered a part of the family where primarily the father had encountered personal persecution (HS 2017). The fact that she has never lived separately from her parents did not count in the decision. Similarly, a young woman with two young children was being separated from her husband who gained a personal refugee status (HS 2016). Their toddler was banished with the mother while the baby, still breastfeeding, was allowed to stay in Finland with the father. Many unaccompanied minors do not even seek family reunion as the tightened policies make it nearly impossible to achieve (Honkasalo et al. 2017). ${ }^{1}$ For example, the young Somali refugee whose familiality is analyzed in this paper had no opportunities to be united with his family as his single-parent mother died soon after he left Somalia at the age of 14 . The little sisters could not be united with him, as they were not considered a family anymore.

These tightened refugee policies urge refugees to come up with novel maneuvers that allow them to seek desirable lives together, keep up hopes for a familial future in a safe environment, and maintain affective relations over long physical distances. Concurrently, people continue their familial lives by establishing new familial relations, within and beyond refugee communities. Familial activities are often hidden or disguised, as they do not always fall within what is expected from asylum seekers, thus they remain poorly known and understood in the present scholarly literature and the humanitarian aid system. Those aware of the active familial means of refugees - refugee communities, activists, support groups, and professional and individual people providing help - are often careful not to disclose them as that information could be used against refugees in institutional processes.

Silencing the whole matter is adopted as an ethical stance by many. To me, refraining from talking about these agencies does not appear as an adequate option. I agree with Baines (2015) in that the attempts to silence people's agencies in precarious positions comes to strengthen the idea of victimized people at the

\footnotetext{
${ }^{1}$ Among other things, these include negative and short-term asylum decisions, which enables deportation as the youth turn 18.
} 
Author's copy. The original article has been published in Emotion, Space and Society (online 1 September 2018, doi.org/10.1016/j.emospa.2018.08.002). For citation, please use the original.

mercy of others. As I see it, the acknowledgement of emotion-laden intergenerational agency, in particular, in these stressful situations insists on less individualistic refugee policies and practices. Importantly, it offers recognition to refugees as political subjects with intimate ties and humane feelings. Taking this approach obviously requires commitment to following discreet research ethics at all stages of the study.

\section{Familial political agency}

The theoretical motivation for studying familial refugee agencies stems from my previous research. I have found that analytical focus on families opens up opportunities to identifying political agency as an activity intertwining personal and communal dimensions (Kallio 2012, 2014, 2016a, 2016b; Häkli and Kallio 2018; Kallio and Häkli 2018). It helps to distinguish between people's subjective capacities to act and the intergenerational activities of mundane communities, without setting them against each other as sources and mobilisers of political agency. What this perspective comes to highlight, especially, is that beyond formal practices and conventional forms of politics, political agency is developed and practiced subjectively and through sharing, leaning on emotional bonds and affective relations. ${ }^{2}$ Thus, political agency cannot be reduced to individualistic competences yet it always relies on personal experiences by which people can relate with each other (Häkli and Kallio 2014, 2018).

In keeping with this idea the paper considers all family members equally as political subjects with capacities to political agency - be they children or adults, male or female, learned or uneducated, able or disabled, mentally healthy or traumatized, on the move or staying behind, with or without formal status, and coming from any country or region with different political systems and socio-cultural norms. This is not to suggest that all people acquired similar political agencies as cultural backgrounds and social positions strongly condition political subjectivities and provide for distinct opportunities to develop and enact political agency (on political socialization see Kallio 2018a). Quite the contrary, there is great variation in

\footnotetext{
${ }^{2}$ Following a similar conceptual line as Sara Ahmed (2014), I am not drawing from a particular 'affect theory' but use emotion and affect as interlinking concepts, where emotion refers to personal experiences that can be shared with others whereas affect is something that people can feel, experience, and enact only intersubjectively, which again may effect their subjectivities and emotional experiences.
} 
Author's copy. The original article has been published in Emotion, Space and Society (online 1 September 2018, doi.org/10.1016/j.emospa.2018.08.002). For citation, please use the original.

refugee political agencies and, as this article argues, familial positioning and relations are among the important conditioning elements.

Methodologically I draw from a broad conception of the political that differs notably from the lay use of the term, not least in the highly politicized refugee context. I identify political aspects of mundane agency from the importance that people give to specific activities, relations, events, people, situations, outcomes, et cetera. This import is experience-based, involves emotional undertones, and forms contextually. As I have outlined with Jouni Häkli, "political meanings are always generated by people [who have found certain issues] particularly important and their related activities have led to broad politicisations" (Kallio and Häkli 2017, p.99, emphasis in original). Political potential can thus be identified from all social life unfolding in people's lived realities, in various forms of "purposive action to either restore the possibility to reproductive agency or to invent transformative forms of action" (Häkli and Kallio 2018, p.69).

The idea of sharing as the basis of familial political agency is relational also spatially. Regardless of where it takes place and with whom it happens, sharing between political subjects may lead to generating feelings, attitudes, ideas, views, relations, orientations, opinions, connections, responsibilities, solidarities, et cetera, which may again bring about active agency with transformative or sustaining aims and effects (cf. Bartos 2018; Hanrahan 2018). People may also open up each other's minds and grasp better understandings about the conditioning elements that constrict their agencies, thus gaining thinking tools for resisting inequalities in their present and future situations (Evans and Thomas 2009; Kivistö and Vecchia-Mikkola 2015; Peña and Ybarra 2017, also Kallio 2018a). Mundane politics can hence be traced, not from certain kinds, but as particularly motivated activities. As this is a theoretically informed way of understanding politics, I do not expect the research participants to consider their mundane activities as political in the same sense (yet they may of course do so).

As familiality takes many forms and unfolds contextually, familial political agency is diversified. The scope of intimate connections that people can form is conditioned, spatially as well as socially, culturally and economically (e.g. where one lives and may dwell, what resources are at hand, which norms shape everyday activities). People's access to communal life also fluctuates over the lifecourse, and social 
Author's copy. The original article has been published in Emotion, Space and Society (online 1 September 2018, doi.org/10.1016/j.emospa.2018.08.002). For citation, please use the original.

relations vary in intensity and length. Whereas some familial relationships are enduring, others appear particularly meaningful in specific moments (which does not place them in a hierarchical order, as brief yet intense encounters may also be influential). Sharing intimate feelings and thoughts is also a matter of personal choice. Some people are more inclined to sharing from themselves as political persons while others carefully consider this kind of interaction, which is only emphasized when sharing and its results become public. This again points towards noticing subtle politics practiced through affective relations alongside with openly political activities.

\section{Familial agency in the lives of young male refugees}

The paper draws from selected in-depth interviews conducted in two research projects. Both followed an ethically sensitive approach where the participants could define what they do and do not want to share with the researchers, about their lives, worldviews, experiences, thoughts and feelings. We were also attentive to power relations and cultural positioning in the ethnographically oriented research settings and balanced them by offering the participants' the lead in the interviews that, overall, were designed as openended and informal discussions. We provided them detailed information about the studies in advance, explained how the materials would be used, offered the opportunity to get in touch with us later, and made the research results available through open access publications. All interviews were recorded and transcribed. I have corrected the language in places, as necessary for comprehension, and changed details for securing anonymity. The names used in the analysis are pseudonyms except for Imran who requested to be introduced with his own name.

The first study focused on experienced political realities of children (10-11 yrs) and young people (1618 yrs) in Northern England, including 134 participants (2014-2015). I have picked one interview from this study, from an Afghan boy (most likely with refugee status and UK citizenship) who participated as part of his school class. The participants were not selected by particular criteria; they are 'ordinary kids' with whom we explored what the world is like in the eyes of children and youth, and not many refugees were 
Author's copy. The original article has been published in Emotion, Space and Society (online 1 September 2018, doi.org/10.1016/j.emospa.2018.08.002). For citation, please use the original.

included in the study. The interviews took place in a school setting and focused on the participants' mundane political experiences and understandings. ${ }^{3}$

The other research project, carried out with Elisa Pascucci and Jouni Häkli, focuses specifically on the experiences and agencies of refugees. During the winter of 2016-2017, we worked with refugees in a reception center in Southern Finland, and interviewed six men (Iraqi, Somali) and five families (Afghan, Iranian Afghan) about their refugee journeys. From this study, the analysis engages with the experiences of the six young men on their twenties, one Somali (refugee status) and five Iraqi (asylum seekers). The discussions were carried out in English and/or Arabic, depending on what the participants felt comfortable with, partly relying on simultaneous interpretation provided by a volunteer. As one of us understands Arabic rather well, we could follow the interpretation closely and felt that it succeeded well. Additionally, we consider non-verbal communication an important element of the discussions, especially in conveying emotions (for more details see Häkli et al. 2017; Pascucci et al. 2018; Kallio et al. forthcoming).

The following analysis focuses on familial agencies of young male refugees. On one hand, this is because they form a greater part of asylum seekers in Finland, with Iraqis as a vast majority (Migri 2017). Studying familial political agency of young men also offers a particularly interesting case as their politics are typically linked with public and collective action rather than emotional intimacies, affective relations, or mundane political activities (cf. Evers 2010). With this focus, the paper can clearly cover just some forms of familial political agency (for related results see Kallio 2018a, 2018b; Kallio and Häkli 2018).

Before turning to the analysis one conceptual clarification is in place. The participants in the latter study talked about themselves as refugees. Yet, de jure, most of them were not. As a status, refugee identity is granted by a state or the UNHCR. Regardless of these positional differences, I consider all participants as refugees de facto, following the spirit of the UNHCR 1951 Convention Relating to the Status of Refugees, where refugeeness is not considered only a formal identity or status but a process with varying phases and stages.

\footnotetext{
${ }^{3}$ Previous results and a detailed description of the study, e.g. Kallio 2014, 2016a, 2016b, 2018a, 2018 b.
} 
Author's copy. The original article has been published in Emotion, Space and Society (online 1 September 2018, doi.org/10.1016/j.emospa.2018.08.002). For citation, please use the original.

\section{Empowered by familial agency}

This section focuses on the familial agency of Imran who arrived in Finland from Somalia in 2013 as an unaccompanied minor. Turning 21 during our interviews, he had left Somalia when 14, urged by his mother who saw that he had to get away from the oppressive situation. As it often is with unaccompanied minors, Imran's reasons for leaving have to be understood in both macro and micro frameworks. In a macro perspective, he had born into a country where a clan-based civil war had surfaced for ten years or so, continuing to this day. As his parents were from different clans there were obvious discrepancies in the family, and they faced challenges in their communities. While Imran's father spent little time at home and remained rather distant to him, he had always been very close to his mother, to the extent that his sisters thought that she "always loved you more than all of us", as one of them had recently conveyed to him. On one hand, this close relationship had been the most rewarding. Imran had learned a great deal from his compassionate mother with whom he spent all days.

Imran: I learned from my mother that, you have to be patient with everybody. You have to respect everybody. Treat everybody equal, as you wanted to be treated, and never let anyone, or humiliate anyone, or disrespect them for some reason. It does not matter where they're from, how they look. So everywhere I go, that's how I deal with people. [...] One thing that my mother was, I would say, the foundation that taught me everything that I'm using today.

On the other hand, the special relationship had made him a target to the father's relatives who treated both him and his mother badly.

Imran: They just thought that, because my mum and my father are different clan, and my mum's clan is the one that they always kind of, depressed them and saying that they're not 
Author's copy. The original article has been published in Emotion, Space and Society (online 1 September 2018, doi.org/10.1016/j.emospa.2018.08.002). For citation, please use the original.

good. So they kind of put me in that label with her. When I was with them, they abused me in so many ways that they could.

In Imran's experience, inequalities embedded in intergenerational power relations - stemming from national-political tensions and actualizing in the familial-political sphere - are an inseparable element of social life. When he arrived in Finland, deeply traumatized, he was unable to communicate this. It took a long time for him to start recovering from his subordinating familial experiences and, still at the time of our fieldwork, he was receiving regular psychiatric treatment. This had however not hindered his development as a political subject, but perhaps the contrary. Imran had gained plenty of capacities to act during the past seven years, and they had started to mobilize into explicit political activities about a year before we met. The year of 2015 with its 'refugee issue' had been pivotal in this regard.

Imran: It happened when the immigrant start to come in 2014. That's when I knew that things changed. I just applied for a volunteer job, and they sent me to the camp. There were 250 people there, from Somalia, to Iraq, and a few of them from Nigeria, or something like that. First I'm just quiet and minding my own business, doing my work. Then something happened, in the camp, and the instructors were starting to be really rude to the immigrants. I really hate when someone bullies someone, or even talk bad to anyone. So from there I started. I just became friends with them while I was working. I would go and visit them, in the rooms, we would talk, I would try to listen to their problems. And from there it hit me like, this is what I'm good at.

This description provides an illustrative example of affective political agency where familiality and political subjectivity intertwine. Drawing from his familial agency, Imran started to take a caring stance in the evolving crisis, acting as a fellow human being from a role that some action researchers call 'expert by experience' (e.g. Videmšek 2017). Concurrently, he commenced building awareness about the emergent destitute situation of refugees in Finland and beyond. He found other people who were similarly concerned 
Author's copy. The original article has been published in Emotion, Space and Society (online 1 September 2018, doi.org/10.1016/j.emospa.2018.08.002). For citation, please use the original.

about it and became engaged in activities that seek to challenge the status quo. Currently, he not only volunteers at the reception center but also takes part in openly political activities, including collective action and public discussions, in collaboration with activists and critical scholars (e.g. the movement Vapaa liikkuvuus, public protests, panel discussions at the university, 'coffee without borders' meetings). To underline, he explicitly brought up the emotionally intense familial agency shared with his mother as the main resource for all this activity.

As a political subject, Imran is hence tightly connected with his maternal family. During his time in Finland, he had first found ways to continue this agency with his little sisters in Somalia, by caring for them from the distance and keeping up the responsive ties together (cf. Duque-Páramo 2013). The communities forming around refugees during 2015 enabled him new, empowering ways to enact familial responsibility.

Imran: Whoever comes to my life, I feel like I'm their elder, even when they're older than me. Like my friends, they call me their father. And I laugh and I'm like 'how am I your father'? We're only three years apart!

Imran's volunteering activities had grown in importance day by day, now filling the whole of his life in his own words, as well as his heart and his head: "I will even consider them more as my family, than I would my own blood family." As his final words regarding this "familiality of choice", Imran describes what he had understood whilst establishing the amiable relations: "We should give each other a chance, to get to know one another. Because if we don't then, what's the point of being a human being, at all?"

Another central element of intergenerational agency, relationality of age, becomes apparent through Imran's sense of self. As a political subject, he surely is 'aged' but his ageness is not based on categorical generational roles, positions, or orders. By chronological age (21) and life situation (no education, living on his own, not in working life), Imran is considered 'youth' in the Finnish society that strongly supports him towards fully liable adulthood. On the contrary, in his everyday communities he appears as a mature young man who has taken care of himself since the age of 14 , concurrently supporting his sisters from the 
Author's copy. The original article has been published in Emotion, Space and Society (online 1 September 2018, doi.org/10.1016/j.emospa.2018.08.002). For citation, please use the original.

distance. In the recent years, he has taken up responsibilities side by side with adult volunteers in the highly politicized refugee situation. Both of these aged subject positions are constitutive of the intergenerational agencies Imran is involved in. He laughs at the idea that guys of the same age or older consider him their elder or father but, in the next sentence, tells us how he has taken care of his sisters back in Somalia over the years as the oldest member of the family, whose share of familial responsibility is obviously heaviest.

By the help of his psychiatrist, Imran has learned to take distance from the identity of the molested child who trusts no one and has no interest in life, albeit he still feels to be that boy as the clan-based powerladen heritage is part of his subjectivity. In the caring communities gathered around reception centers, he has found opportunities to relate with alternative identities (cf. Kivistö and Vecchia-Mikkola 2015). There he has come to be recognized as a knowledgeable and skillful young man, a role model for anyone who wishes to become a refugee in Finland. The combination of this affective recognition and his strong commitment to familial solidarity are currently shaping his political subjectivity, leading to empowered intergenerational agency.

\section{Taking political positions through familial agency}

The second example comes from a 17-year-old Afghan boy who has lived practically all of his life in Northern England where his family sought asylum in the late 1990s. Mukhtar considers England and Afghanistan equally as his home countries. He has family in a number of European countries, like many Afghan refugees, as people have left the country at different times. His conception of familiality is broad, including 'small' families within the 'big' family (cf. Harker 2010: 2629). In Mukhtar's view, notable divisions exist within the big family. Whereas his small family in England and another family in Denmark share an emphatic and respectful relationship with the family back in Afghanistan, another two families in Germany and Netherlands have grown selfish and distanced from them. Visiting them - which his parents sometimes choose for them to do - is unpleasant to Mukhtar: 
Author's copy. The original article has been published in Emotion, Space and Society (online 1 September 2018, doi.org/10.1016/j.emospa.2018.08.002). For citation, please use the original.

Mukhtar: They don't have an idea of what goes on around the world, they don't understand poverty. I mean in my family, we really focus on charity, but they, them guys just spend it on other things, pointless things. It doesn't make sense to me, to be honest.

Interviewer: So they don't have like other people, they don't understand that there is like injustice kind of thing...?

Mukhtar: Well they do but they just ignore it. It's what makes them so ignorant.

To Mukhtar, familial agency is primarily about mutual respect and responsibility, and caring relations. In his view, the big family should work as a common context of wellbeing, small families supporting each other with the resources they have. Mukhtar's family in England keeps contact with the family in Afghanistan on a daily basis, including hours long Skype calls every Sunday. They also pay a visit every year during the summer holidays and send over money as they can. The following accounts on Afghanistan describe well how important these affective familial activities are to Mukhtar:

Mukhtar: The actual perception is, the rich live a good life and the poor live a bad life. That's literally it. The government there, they make the wealthy wealthier and the poor poorer. I mean there, there's nothing to help them. There isn't even a state benefit, they have to make their own money. Everyone does. That's why it's so... the government have no power. People can do what they want, they easily bribe their way through. Injust country, yeah. I know a guy who got killed, and they took him [the killer] to court. He bribed the judge and got nothing. He didn't even go to jail. He knew people in the government and paid them off. Like literally, a corrupt government. Interviewer: And again, are these things you talk about with your parents or your family? Mukhtar: Yeah, every night. It really opens up your mind about the world. It gives you two different sides to it, the well off and the poor. 
Author's copy. The original article has been published in Emotion, Space and Society (online 1 September 2018, doi.org/10.1016/j.emospa.2018.08.002). For citation, please use the original.

Mukhtar: I don't mind going there, it's just every time I go there there's an explosion. It's a war zone isn't it. I've been there and seen a place get blown up about 20 meters away from me. It's really dangerous. But I don't really mind going there, to see family, its good.

These excerpts describe the Afghanistan Mukhtar knows and feels for with his family. By sharing the affective relations in his big family, maintained actively together with his parents and the other committed small families, he has learned how to continue and perhaps repair this life, as a caring political familial subject (Bartos 2012). Leaning on his strong personal stance, he makes use of the capabilities to share familiality through emotional encounters, aligning with similar minded people and withdrawing actively from the alienating relations, the latter including outspoken critique. Following Fisher and Tronto's (1990) classical conceptualization, as part of his family Mukhtar is actively taking a position in a politics of care that seeks to continue and repair the world "so that we can live in it as well as possible" (p.40), in England, Afghanistan, and elsewhere (cf. Habashi 2017 on Palestine). This developing intergenerational political agency is not restricted to his familial life but unfolds in other contexts as well, as an established attitude towards geopolitical and transnational inequalities for instance. This became explicit as our discussion regarding Afghanistan continued to the war itself, which I do not have the space to discuss further here.

Concerting what I have brought up in this section, the results from the broader study where we interviewed 23 students in Mukhtar's class, 38 same-age youth in another English town, as well as 73 younger children, point towards age relations as significant elements during the early years of life in shaping up political subjectivities (Kallio 2018a, 2018b). Like Mukhtar, many of the participants told about their families as contexts where they could feel, think, speak and act together, as particular kind of selves who could stand with or apart from their siblings, mothers, fathers, grandparents, and other people of kith and kin, depending on how they felt about a specific matter. This underlines that growing into political agency is an affective process of sharing and evolving subjectivities, which radically contrasts with conventional ideas of top-down political socialization (Kivistö and Vecchia-Mikkola 2015; Habashi 2017). As 
Author's copy. The original article has been published in Emotion, Space and Society (online 1 September 2018, doi.org/10.1016/j.emospa.2018.08.002). For citation, please use the original.

political persons, we exist only as intersubjects who can actively seek for personal stances in the political realities encountered with others.

\section{Preserving humanity in familial agency}

The last analytical section discusses the experiences of five young, single Iraqi men. As refugees, they are building futures primarily for themselves, with forthcoming and left-behind families in mind. They had known from the start that opportunities to creating a new life in Europe would probably involve little physical nearness with their parents, siblings, and other family members in Iraq. The actual moments of leaving had thus been loaded with ambiguous emotions:

Samer: My father and mother say, go away, because here is no life, there is no future. If you stay here, the militia or the mafia will kill you, and we don't need to die. Please go away from this country. [...] It is really hard feeling. It's going from your family, going from all your friends, going from your mother country, and everything you love, everything you like, everything you need. Then when you go to other countries, there is no one, just the Red Cross.

Akram: I still remember that feeling. When we get in the boat I just - the final state of my life. I can't return back to Iraq anymore. In some point I was thinking that there's still hope that I go back to my family. In the first minutes in the boat, I was thinking that that's it, that's the final decision I made: If something happen in the boat and if they took us to Turkey, I don't care I will go back to Iraq. But nothing happened and we reach Greece.

The parents and siblings of Samer and Akram, as those of Salih and Ibrahim, were living in Iraq, in addition to which Akram had brothers in Germany and the US. Fadhil, who had turned 18 during his journey through Europe, had become an orphan when he was a child, with one sister now married in Iraq. In the interviews 
Author's copy. The original article has been published in Emotion, Space and Society (online 1 September 2018, doi.org/10.1016/j.emospa.2018.08.002). For citation, please use the original.

with these five young men, family came up in three politically inclined meanings. They talked about, first, their close families, second, what family means in Iraq, and third, familiality in Finland.

Akram and Salih continued to have close relations with their families, they could keep contact on a daily basis through social media applications. Fadhil and Samer had heard close to nothing from their families since they left, regardless of constant attempts. Ibrahim expressed bitterness towards his family and said nothing about this matter. His description of familial agency provides one example of how families can act affectively with various kinds of political outcomes. This is how our interpreter formulated his thoughts, following a strongly emotional account by Ibrahim (could not be interpreted simultaneously for ethical reasons):

Ibrahim: He was not good with Christian people. But he think that he was not good person there [sic], because if he saw Christian people then [sic] he was teasing them or annoying them by words. And he don't blame himself because they didn't teach him. He blame his family. He blame the community there because they didn't teach us [sic] well, how to act, or they didn't teach us how to talk with different religion or different kind of people. So he think it's not his fault.

This description of how familial life can lead to prejudiced political agency - as a personal stance yet firmly backed up by the family, local community, and the society as a whole ${ }^{4}$ - bears some characteristics to what seems to have happened largely to familial living and relations in Iraq over the conflict-ridden years (cf. Sassoon 2008, 2016). During our long conversation on the topic, Ibrahim and Akram together contextualized and generalized this experiential knowledge, underlining that Ibrahim's bigoted agency had emerged there and then, resulting from how we Iraqis are brought up and educated. In line with this, Akram described how turning inhumane in contemporary Iraq can happen to anyone, especially due to committed familial relations that cannot anymore be separated from the militarized and radicalized clans.

\footnotetext{
${ }^{4}$ The person is from a Sayyid family, thus having a highly respected social position. The subject position he had been offered from early on was hence embedded not only in his family or close community, but also in the broader Iraqi/Muslim society.
} 
Author's copy. The original article has been published in Emotion, Space and Society (online 1 September 2018, doi.org/10.1016/j.emospa.2018.08.002). For citation, please use the original.

As Sassoon (2016: 26) describes the situation, "Ordinary citizens, who are victims of corruption, are being pushed into becoming part of the corrupt process by backing sectarian groups." Akram explicitly termed the degeneracy of familiality as the main reason for his escape:

Akram: In Iraq, if you stay there, at some point you have to fight someone. For example some people, if their father get killed from the militia, he will start to hate them. He will join some other militia to fight them, and then he will lose his heart. His mind I think in the beginning, and then his heart. I don't have the word for them. Because they are not animal. The animals have feelings too. They're even worse than, there is no word for that. The most shocking thing is that they are proud of what they do. Thank god that I haven't been in this situation but if I'm still there maybe I will be. And that's what I don't want.

Without an aim to make general claims about the current situation in Iraq, I present these examples to show that, to these young men, familial solidarity and care appear as complex matters far from innocent amiability. In the Iraq that they know, emotionally dense family relations are publically recognized, may engender tremendously affective agencies and thus empower people in their communities, yet often with horrible outcomes (cf. Baines 2015). Both of them expressed that they left precisely to avoid active engagement in familial (clan) networks. A society where familiality is joint with brutality, they stated, does not offer opportunities to building humane lives, which is what they are hoping to accomplish in Europe. This aligns with the findings by Kivistö and Vecchia-Mikkola (2015: 93): "Words such as democracy, peace, respect for the law, normality, and freedom were frequently used to contrast Helsinki to the Iraqi cities."

In addition to our participants' personal circumstances, our study sheds light on people's uneven opportunities to get away from distressing life situations. For example Akram told us that he still has two brothers and four sisters in Iraq, as well as his parents. They find it much more difficult to leave as they have already established their own families, which bonds them intergenerationally to the local communities and family networks from both sides. Here familiality reveals, again, its two-faced appearance: It concurrently provides people a firmer status in their communities and binds them tighter to 
Author's copy. The original article has been published in Emotion, Space and Society (online 1 September 2018, doi.org/10.1016/j.emospa.2018.08.002). For citation, please use the original.

these communities, which may abruptly ruin their familial lives if (or when) they become challenged.

Limited opportunities to flee concern females, specifically, as it is much harder for young women to leave their families and the country alone. Herein the relationality of age in intergenerational relations becomes visible, this time as a gendered characteristic (for a thorough discussion on female positions in Iraq, see AlAli 2007).

Acknowledging concurrently the intimate familial relationships that Iraqi refugees cherish, and the politicization of familial relations in public life in Iraq makes understandable why our participants sometimes compared their current relationships and communities to their familial lives back home, like Samer: "I have many friends here. Like, same my family. Yeah, everyone here nice, everyone friendly. It's nice country." Even if they cannot bring their families physically with them, they see the opportunity in Finland to continue the lives that would probably be destroyed in the hostilities of Iraq, Somalia or Afghanistan, including the risk of turning into 'familial abjects'. In other words, they are preserving humanity in their families by moving away from the society where they are being dehumanized.

This piece of analysis has emphasized that, whilst seeking asylum as individuals, even single people may become refugees as familial subjects, drawing from their (un)caring familial politics. Like Imran's and Mukhtar's cases portray, turning away from destructive or alienating familiality can happen by strengthening those family relations that one cares for (often over distance) and creating new trusting relationships with people who can share one's current life situation (familialities of choice). These relationships can be fostered with local people as well, as the final quote that I present shows. It is about an affective situation experienced by Akram at the Finnish-Swedish border, more precisely the twin city of Haparanda-Tornio that provided a gateway to Finland for most refugees who arrived in 2015 (more than 10000 registered asylum seekers):

Akram: There in the border I remember one of the women, she was giving clothes to us. When people said "we don't need this jacket" she just told that "You don't know. You need it." [laughter] "This month is good but next month it's too cold. I'm your mother now. Just take it and don't say anything." She was 
Author's copy. The original article has been published in Emotion, Space and Society (online 1 September 2018, doi.org/10.1016/j.emospa.2018.08.002). For citation, please use the original.

like this. Really, we just, laugh and we feel how she care. We know that she care a lot. And she's

repeating that "I am your mother here. You don't have mother so I am yours." And that was so nice.

\section{Acknowledging refugee familial agency as a productive capacity}

During the spring of 2017 when this paper was first written, the longest refugee sit-in in the Finnish history was going on in central Helsinki, titled Right to Live. Between February 10 and September 4 2017, asylum seekers mainly from Iraq and Afghanistan protested against the tightened policy line of the state, and the practices of the migration office and courts that, together, are making it nearly impossible for many people to gain asylum in the country. Most of the protesters were young men. No one can deny the political relevance of their activities that have gained attention and support locally, nationally and internationally. They are acts of citizenship, practiced by those with no part in the Finnish polity, turning the 'noise' of denizens into a 'voice' of refugees (Isin 2012).

Concurrently, thousands of refugees, from babies to elderly persons, are spending their days in reception centers and apartments appointed to them with little or no connection to activism. They follow Facebook accounts and exchange messages with their close ones, share their feelings and thoughts with other asylum seekers and volunteers, help each other as they would their family, and create affective connections with local people. Joint dinners with traditional foods are organized together, rooms are furnished in a Middle Eastern style, and information about shops selling familiar delicacies is shared. Volunteers collect and deliver supplies to families, especially when children are borne. Children play with other kids at their reach, picking up Finnish through which integration starts to proceed. Young people seek to enjoy themselves and connect with other youth, engaging with the urban fabric where belonging is about active presence more than formal status.

Such activities are a largely neglected form of political agency that refugees collaboratively practice. Their emotion-laden, affective agencies draw attention to mundane politics where acting for and against matters that seem important is central. By analyzing these intimate relations and activities, this paper has argued that political agencies of refugees develop and mobilize importantly as familial agencies. Their 
Author's copy. The original article has been published in Emotion, Space and Society (online 1 September 2018, doi.org/10.1016/j.emospa.2018.08.002). For citation, please use the original.

practices of care - as part of transnational 'big families' or in self-established 'families by choice', for instance - are non-individual agencies. Even a single young man who seems to be acting as himself and for himself may practice agency strongly embedded in familiality. The capacities gained and enhanced in everyday communities may feed into collective activities and groups with explicitly political aims, actualizing in the public realm, but not necessarily. Familial agency has political relevance also in the private sphere where awareness building and subtle transformative moves unfold.

By introducing different forms of agency the paper has set out to challenge the conception that political agencies bolster particularly when people are supported by institutional means as citizens and have good resources and enhanced opportunities to learn how to act politically. Highlighting an alternative viewpoint, the analysis has identified the development of political agency as particularly heightened in challenging situations where people have hindered opportunities to act on their own grounds and where their progressive agencies receive little institutional support, yet where they are striving to change the course of their lives in extremely stressful situations through the available means. In conclusion, I suggest that paying more attention to these agencies would benefit both the humanitarian aid system that largely relies on self-help, and the refugees who are establishing new lives as part of their families whether institutionally encouraged to do so or not.

Understanding the plurality of familial agency requires further research that can provide important insights to the transnational humanitarian aid system. As amiable social ties are particularly lasting and familial agencies motivated, refugees could contribute a great deal more when recognized through familial frameworks. This of course requires a respectful approach instead of exploitation that is sometimes identified from self-help policies (e.g. Pascucci 2016). If the states and the UNHCR started seeing familiality as a resource rather than a problem - like many informal actors already do - they could rely more on the active agencies of refugees during asylum seeking and after. Identifying the productive capacities embedded in families, of various kinds, would provide for organizing the daily lives of refugees and enhancing communication with and between different institutional actors, for instance. As one example, the quickly developing social and linguistic skills of children and youth are presently largely ignored, whilst 
Author's copy. The original article has been published in Emotion, Space and Society (online 1 September 2018, doi.org/10.1016/j.emospa.2018.08.002). For citation, please use the original.

they could be relied on in communication between refugees and institutions. Living arrangements could also be rethought from familial perspectives. For example, a liberal, unmarried Iranian Afghan woman who is seeking asylum with his partner and newborn children, and running away from her patriarchal family, is not in a supportive environment among Afghan families with traditional values.

Secondly, the recognition of familiality as an inseparable dimension of refugeeness acknowledges migrants primarily as human beings who, like everyone else, do not exist as mere individuals. The approach on intergenerationality put forward in this paper begins from the idea that people are emotionally related intersubjects. Be they blood ties or other intimate relationships, familiality is central to the establishment of political subjectivities, beginning from childhood and continuing throughout the life course. Familial political agency can thus be seen as a medium for the overall wellbeing of people (cf. Spellings et al. 2012). Making visible how children, youth, women, and men act as affective political subjects in their transnational everyday lives - taking intergenerational responsibilities and caring for the people with whom they share their refugeeness - is one way of respecting migrants in their various formal and informal positions as capable actors, in the challenging and vulnerable life situations they often face.

\section{References}

Ahmed, S. (2014). Afterword: Emotions and their objects. In Ahmed, S., The Cultural Politics of Emotion, second edition, pp.204-33. New York: Routledge.

Al-Ali, N. S. (2007). Iraqi Women: Untold Stories from 1948 to the Present. London: Zed Books.

Baak, M. (2015). Transnational families, remittances, cieng and obligation for Dinka women in Australia. Emotion, Space and Society, 16, 123-129.

Baines, E.K. (2015). "Today, I want to speak out the truth": Victim agency, responsibility, and transitional justice. International Political Sociology, 9(4), 316-332.

Bartos, A. E. (2012). Children caring for their worlds: The politics of care and childhood. Political Geography, 31(3), 157-166. 
Author's copy. The original article has been published in Emotion, Space and Society (online 1 September 2018, doi.org/10.1016/j.emospa.2018.08.002). For citation, please use the original.

Bartos, A. E. (2018). Relational spaces and relational care: Campus sexual violence, intimate geopolitics and topological polis. Area. EarlyView. Doi: 10.1111/area.12449

Beier, K., Jordan, I., Wiesemann, C., \& Schicktanz, S. (2016). Understanding collective agency in bioethics. Medicine, Health Care and Philosophy, 19(3), 411-422.

Duque-Páramo, M.C. (2013). Colombian families dealing with parents' international migration. McCarthy, J. R., Gillies, V., \& Hooper, C. A. (Eds.) Family troubles? Exploring changes and challenges in the family lives of children and young people. Bristol: Policy Press, 209-222.

Erel, U. (2011). Reframing migrant mothers as citizens. Citizenship Studies, 15(6-7), 695-709.

Evans, R. (2013). Young people's caring relations and transitions within families affected by HIV. In McCarthy, J. R., Gillies, V., \& Hooper, C. A. (Eds.) Family troubles? Exploring changes and challenges in the family lives of children and young people. Bristol: Policy Press, 233-243.

Evans, R. \& Thomas, F. (2009). Emotional interactions and an ethics of care: Caring relations in families affected by HIV and AIDS. Emotion, Space and Society, 2(2), 111-119.

Evers, C. (2010). Intimacy, sport and young refugee men. Emotion, Space and Society, 3(1), 56-61.

Fisher, B. \& Tronto, J. (1990). Toward a feminist theory of caring. In Emily K. Abel and Margaret K. Nelson (eds.) Circles of Care: Work and Identity in Women's Lives, pp.35-62. New York: State University of New York.

Habashi, J. (2017). Political Socialization of Youth: A Palestinian Case Study. New York: Palgrave Macmillan.

Häkli, J. \& Kallio, K.P. (2014). Subject, action and polis: Theorizing political agency. Progress in Human Geography, 38(2), 181-200.

Häkli, J. \& Kallio, K.P. (2018). On becoming political: the political in subjectivity. Subjectivity, 11(1), 57-73. Häkli, J., Pascucci, E. \& Kallio, K.P. (2017). Becoming refugee in Cairo: The political in performativity. International Political Sociology, 11(2), 185-202.

Hanrahan, K. B. (2018). The spaces in between care: Considerations of connection and disconnection for subjects of care. Area. EarlyView. Doi: 10.1111/area.12486 
Author's copy. The original article has been published in Emotion, Space and Society (online 1 September 2018, doi.org/10.1016/j.emospa.2018.08.002). For citation, please use the original.

Hayden, B. (2006). What's in a name? The nature of the individual in refugee studies. Journal of Refugee Studies, 19(4), 471-487.

Hedlund, D. (2017). Constructions of credibility in decisions concerning unaccompanied minors. International Journal of Migration, Health and Social Care, 13(2), 157-172.

Honkasalo, V., K. Maiche, H. Onodera, M. Peltola \& L. Suurpää. (eds). (2017). Young People in Reception Centres. Finnish Youth Research Society, Finnish Youth Research Network, Internet publications 121. http://www.nuorisotutkimusseura.fi/julkaisut/verkkokauppa/verkkojulkaisut/1749-young-people-in$\underline{\text { reception-centres }}$

HS (2016). Mother and a three-year-old are being deported from Finland - father and baby may stay, A piece of news in the leading national newspaper. http://www.hs.fi/kotimaa/art-2000002904750.html [Visited 12.4.2017]

HS (2017). Migration office breaks an Iraqi family "Threats and extortion have been directed primarily at your father, thus your fear is not objectively justified", A piece of news in the leading national newspaper. http://www.hs.fi/ulkomaat/art-2000005093265.html [Visited 12.4.2017]

Isin, E. (2012). Citizens without Frontiers. London: Continuum.

Jacobsen, M. (forthcoming). Reversing the gaze: Syrian forced migrants' perceptions of 'becoming' an asylum seeker, a refugee, a guest in Denmark. [in process]

Kallio, K.P. (2012). Desubjugating childhoods by listening to the child's voice and childhoods at play. ACME: An International E-Journal for Critical Geographies, 11(1), 81-109.

Kallio, K.P. (2014). Intergenerational recognition as political practice. In Vanderbeck, R. and Worth, N. (eds) Intergenerational Space, 139-154. London: Routledge.

Kallio, K.P. (2016a). Living together in the topological home. Space and Culture, 19(4), 373-389.

Kallio, K.P. (2016b). Becoming geopolitical in the everyday world. In Benwell, M. and Hopkins, P. (eds.) Children, Young People and Critical Geopolitics, pp. 169-186. Aldershot: Ashgate.

Kallio, K.P. (2018a) Citizen-subject formation as geo-socialisation: a methodological approach on 'learning to be citizens'. Geografiska Annaler B: Human Geography, 100(2), 81- 96. 
Author's copy. The original article has been published in Emotion, Space and Society (online 1 September 2018, doi.org/10.1016/j.emospa.2018.08.002). For citation, please use the original.

Kallio, K.P. (2018b) Exploring space and politics with children: A geosocial methodological approach to studying experiential worlds. In CutterMackenzie, A., Malone, K. and Barratt, E. (eds.) Research Handbook on ChildhoodNature, 1-28. Singapore: Springer.

Kallio K.P. \& Häkli J (2017). Geosocial lives in topological polis: Mohamed Bouazizi as a political agent. Geopolitics, 22(1), 91-109.

Kallio K.P. \& Häkli, J. (2018). Care as mundane politics in contested familial refugee lives. Gender, Place and Culture. [In press]

Kallio K.P., Häkli, J. \& Pascucci, E. (forthcoming) Refugeeness as political subjectivity: Experiencing the humanitarian border. Environment and Planning C: Politics and Space. [In press]

Kivisto, P. \& La Vecchia-Mikkola, V. (2015). The integration of Iraqis in two European cities: Emotions and identity work. Emotion, Space and Society, 16, 90-98.

Lind, J. (2018). Sacrificing parents on the altar of children's rights: Intergenerational struggles and rights in deportability. Emotion, Space and Society. Online published July 192018.

Doi:10.1016/j.emospa.2018.07.001

Lippert, R. \& M. Pyykkönen. (2012). Contesting family in Finnish and Canadian immigration and refugee policy. Nordic Journal of Migration Research 2(1), 45-56.

Migri (2017). Finnish Immigration Service statistics. http://tilastot.migri.fi/\#applications?l=en\&start=540

[Visited 10.5.2017]

Mitchell, K. \& Sparke, M. (forthcoming), Contending constructions of safe space for migrants in Europe: Hotspot geopolitics vs geosocial solidarity. Environment and Planning D: Society and Space. [in process] Pascucci, E. (2016). Transnational disruptions: materialities and temporalities of transnational belonging among Somali refugees in Cairo. Global Networks, 16(3), 326-343.

Pascucci, E. (2018). Tech camps: Economic subjectivity and the refugee condition in the contemporary Middle East. Geographical Review. [In press] 
Author's copy. The original article has been published in Emotion, Space and Society (online 1 September 2018, doi.org/10.1016/j.emospa.2018.08.002). For citation, please use the original.

Pascucci, E., Häkli, J. \& Kallio, K.P. (2018). "Delay and neglect": The everyday geopolitics of humanitarian borders. In A. Paasi, E.-K. Prokkola, J. Saarinen and K. Zimmerbauer (eds.) Borderless Worlds - For Whom? Ethics, Moralities and Mobilities. London: Routledge. [in press]

Peña, I. \& Ybarra, M. (2017) “We don't need money, we need to be together”: Forced transnationality in deportation afterlives. Geopolitics, 22(1), 34-50.

Sassoon, J. (2008). The Iraqi Refugees: The New Crisis in the Middle-East. London: IB Tauris.

Sassoon, J. (2016). Iraq's political economy post 2003: From transition to corruption. International Journal of Contemporary Iraqi Studies, 10(1-2), 17-33.

Spellings, C. R., Barber, B. K. \& Olsen, J. A. (2012). Political activism of Palestinian youth: Exploring individual, parental, and ecological factors. Journal of Marriage and Family, 74(5), 10841100.

UNHCR. 2001. Family reunification in the context of resettlement and integration. Annual tripartite consultations on resettlement. Geneva, 20-21 June 2001.

\section{http://www.refworld.org/pdfid/4ae9aca12.pdf}

United Nations (1983). UNHCR guidelines on reunification of refugee families.

United Nations Human Rights Committee (1990). General Comment No. 19: Protection of the Family, the Right to Marriage and Equality of the Spouses, 27.7.1990.

Videmšek, P. (2017). Expert by experience research as grounding for social work education. Social Work Education, 36, 172-187.

Williams, J. M. (2015). From humanitarian exceptionalism to contingent care: Care and enforcement at the humanitarian border. Political Geography, 47, 11-20. 